\title{
Functional Jam Production from Blends of Banana, Pineapple and Watermelon Pulp
}

\section{Olugbenga Olufemi Awolu, ", Grace Oluwaseun Okedele ${ }^{1}$, Modupe Elizabeth Ojewumi ${ }^{2}$, Funmilayo Grace Oseyemi ${ }^{1}$}

${ }^{1}$ Department of Food Science and Technology, Federal University of Technology, Akure, Nigeria

${ }^{2}$ Department of Chemical Engineering, Covenant University, Ota, Nigeria

Email address:

oowolu@futa.edu.ng (O. O. Awolu)

${ }^{*}$ Corresponding author

\section{To cite this article:}

Olugbenga Olufemi Awolu, Grace Oluwaseun Okedele, Modupe Elizabeth Ojewumi, Funmilayo Grace Oseyemi. Functional Jam Production from Blends of Banana, Pineapple and Watermelon Pulp. International Journal of Food Science and Biotechnology.

Vol. 3, No. 1, 2018, pp. x-x. doi: 10.11648/j.jjfsb.20180301.12

Received: October 2, 2017; Accepted: December 5, 2017; Published: January 19, 2018

\begin{abstract}
Functional jam from blends of banana, pineapple and watermelon pulp was produced and evaluated. The aim was to develop a locally but nutritionally rich, functional jam. Various blends of the fruit pulp were considered in order to select the best. The percentage compositions of the blends were 50:25:25; 25:50:25; 25:25:50 and 33.33:33.33:33.33 of banana, pineapple and watermelon pulps respectively. In addition to the pulp blends, $2.9 \%$ pectin produced from citrus peel was added together with citric acid, sodium benzoate and sugar. The entire mixture was heated at $110^{\circ} \mathrm{C}$ for 55 to enhance the viscosity of the blends. Proximate analyses, mineral analyses, brix, $\mathrm{pH}$ and Vitamin constituents of the sample were determined. The blend with the best result from the analyses was selected for rheological and sensory evaluations. The best blend was 25:25:50. The result of the proximate analyses of this best blend were $8.58 \%$ protein, $1.41 \%$ fibre, $0.38 \%$ ash, $3.92 \%$ fat, $2.52 \%$ moisture and $83.20 \%$ carbohydrate. The vitamin compositions were; $1.32 \mathrm{mg} / 100 \mathrm{~g}$ vitamin A, $8.22 \mathrm{mg} / 100 \mathrm{~g}$ vitamin C and $0.015 \mathrm{mg} / 100$ $\mathrm{g}$ vitamin $\mathrm{E}$. The $\mathrm{pH}$ was 4.16 , viscosity $58.77 \mathrm{cp}$ while the specific gravity was 1.016 . The mineral compositions of the best blend were $0.34 \mathrm{ppm}$ iron, $28.90 \mathrm{ppm}$ sodium, $80.90 \mathrm{ppm}$ potassium, $1.50 \mathrm{ppm}$ calcium and $0.60 \mathrm{ppm}$ magnesium.
\end{abstract}

Keywords: Jam, Functional, Watermelon, Minerals, Vitamins

\section{Introduction}

Functional food development and consumption is gaining momentum worldwide. Currently, there is an awaken awareness on preventive rather than curative health care. And it has been discovered that consumption of functional foods will serve as vital instrument for preventive health care; globally, the consumption of functional foods is being encouraged. In fact, in bakery products developments, there is a new trend of research into the development of flours with health benefits by incorporating fruit pomaces, fibres and legumes to cereals $[1,2]$.

It has been discovered that fruits contained bioactive compounds which have enormous health benefits [3]. Functional fruits from blends of fruits have been developed [3]. It was established that the blend of fruits consisting pineapple, orange juices, carrot, and Hibiscus sabdariffa extracts have high antioxidants properties in addition to high vitamin $\mathrm{C}$ and carotenoids contents [3]. Some wastes products from fruits especially pomace had also been used to enhance the nutritional quality, in particular the antioxidants properties of composite flours. Specifically, apple pomace was added to a wheat-based composite flour to enhance its antioxidant properties and minerals composition [2].

Fruits are important foods with excellent nutritional and functional properties. Populations that consume diet rich in fruits and vegetables have significantly lower rates of many types of cancers [4]. Fruit and vegetables are either consumed directly or after being processed to products such as fruit purees or jams [5].

Banana is one of the oldest fruits probably originated in the warm moist tropical Asia. Most edible bananas originated 
from two species; M. acuminate and M. balbisiana [6]. Bananas and plantain have the potential of contributing to strengthening national food security and decreasing rural poverty [7]. Banana is an excellent source of vitamin B6, soluble fibre, and contain moderate amount of vitamin $\mathrm{C}$, manganese, and potassium.

Watermelon is a member of the cucurbitaceae family, and it is a warm-season crop related to cantaloupe, squash, cucumber and pumpkin [8]. The whole watermelon is edible, including the rind. It is low in calories but highly nutritious; it contains Vitamin C and Vitamin A in form of the disease fighting beta-carotene. Lycopene and beta-carotene work in conjunction with other plant chemicals not found in vitamin/mineral supplements. Potassium is also available in it which is believed to help in the control of blood pressure and possibly prevent strokes [9].

Pineapple is a tropical fruit which may be enjoyed whole and fresh, juiced or canned [10]. The pulp is yellow to golden yellow, sweet, and juicy, pineapple may be used fresh, juiced, dried, made into candies, and incorporated into cooked dishes and desserts. The fruit is a good source of dietary fibre, loaded with vitamins and minerals, and especially rich in vitamin $\mathrm{C}$ and manganese [10]. It supplies arrays of colour, flavour and texture to the pleasure of eating [11].

Jams are thick; sweet spreads made by cooking crushed or chopped fruits with sugar. They tend to hold their shape, but are generally less firm than jellies [12]. Availability of fruits is seasonal and therefore, jam production from fruits helps the availability of fruits at off-seasons. Jam enjoys substantial shelf life and thus can be made available round the year. Jam production requires right proportion of the right ingredients to get the desired result, which are; fruits, acid, pectin and sugar.

\section{Materials and Method}

\subsection{Materials}

The raw materials are pineapple (Ananas comoscus), bananas (Musa paradisiaca), and watermelon (Citrullus lanatus) which were purchased from Oja Oba, Akure, Ondo State. The apparatus used include $\mathrm{pH}$ meter (HANNA instrument, model 23044), Refractometer (Abbey refractometer) and Rionviscometer (model VA-04F). The reagents which include citric acid, sodium benzoate are all of analytical grade

\subsection{Jam Blends Formulation and Preparation}

Jam components are in ratios $0.45: 0.55$ of fruit pulp: sugar respectively. The formulation therefore consisted of $584 \mathrm{~g}$ fruit pulp and $713 \mathrm{~g}$ sugar. Others were $2.9 \mathrm{ml}$ of pectin, 0.03 $\mathrm{g}$ citric acid and $0.06 \mathrm{~g}$ sodium benzoate. The pulp was made from blends of banana (Musa paradisiaca), pineapple (Ananas comoscus) flesh, and watermelon (Citrullus lanatus) flesh. Each of the fruits were washed, dried, peeled and sliced into smaller sizes for blending. Immediately after blending, they were refrigerated till further use. The mixture of the fruit pulp was boiled for $10 \mathrm{~min}$ to soften the fruit pieces and to pasteurize it. Sugar $(713 \mathrm{~g})$ was added after $10 \mathrm{~min}$ to the boiled pulp while mixing and pectin solution was added as thickener. Preservatives (citric acid and sodium benzoate) were later added to the mixture. After 55 min of mixing, colourant was added and mixed to obtain a uniform and desired colour, and until gelation was formed. The mixture was poured directly into an already sterilized jar and lid, and then cooled in cold water. The sample formulation is presented in Table 1 .

Table 1. Fruits Percentages in Jam Formulation.

\begin{tabular}{llll}
\hline Samples & Banana (\%) & Watermelon (\%) & Pineapple (\%) \\
\hline BWP 1 & 33.33 & 33.33 & 33.34 \\
BWP 2 & 25 & 50 & 25 \\
BWP 3 & 25 & 25 & 50 \\
BWP 4 & 50 & 25 & 25 \\
*MFJ & Control & & \\
\hline
\end{tabular}

*MFJ (Mixed fruit Juice) is a commercial jam sample.

\subsection{Chemical Analysis}

The determination of moisture, ash, protein, fat, crude fibre and carbohydrate were carried out using AOAC methods [13]. Determination of Calcium, Magnesium, Zinc, and Iron was carried out using Atomic Absorption Spectrophotometer while Potassium was determined by flame photometry [13].

\subsection{Vitamins Determination}

For Vitamin A determination, the sample $(1 \mathrm{ml})$ was measured into the test-tube I (centrifugal) with a tight stopper and $1 \mathrm{ml}$ of the $\mathrm{KOH}$ solution was added, the tube was plugged and shake vigorously for 1 minute. The tube was heated in a water bath $\left(60^{\circ} \mathrm{C}, 20\right.$ minutes $)$, and was then cooled down in cold water. About $1 \mathrm{ml}$ of xylene was added, the tube was plugged and shaken vigorously again for 1 minute. The tube was centrifuged $(1500 \times g, 10$ minutes), the whole of the separated extract (upper layer) was collected and transferred into the test tube II made of "soft" (sodium) glass. The absorbance A1 of the obtained extract was measured at $335 \mathrm{~nm}$ against xylene. The extract in the test tube II was irradiated to the UV light for 30 minutes, then the absorbance A2 was measured. The concentration cx of vitamin $\mathrm{A}(\mu \mathrm{M})$ in the analyzed liquid was calculated, using $\mathrm{Eq}(1)$

$$
c x=[A 1]-[A 2] .22 .23
$$

Where: 22.23 is the multiplier received on basis of the absorption coefficient of $1 \%$ solution of vitamin A (as the retinol form) in xylene at $335 \mathrm{~nm}$ in a measuring cuvette, 1 cm thickness.

Vitamin C content was determined by the spectrophotometric method using ascorbic acid as a reference compound. About $10 \mathrm{ml}$ of the juice sample was weighed into $10 \mathrm{ml}$ of water and mixed together. The extract $(200 \mu \mathrm{l})$ was pipetted and mixed with $300 \mu 1$ of $13.3 \%$ of trichloro-acetic acid (TCA) and $75 \mu \mathrm{l}(0.075 \mathrm{ml})$ of Dinitrophenylhydrazyl (DNPH). The mixture was incubated in water bath at $37^{\circ} \mathrm{C}$ for 3 hours. After 3 hours, $500 \mu 1$ of $65 \%$ sulphuric acid was 
added and the absorbance was read with the spectrophotometer at $520 \mathrm{~nm}$. The concentration of vitamin $\mathrm{C}$ was calculated [14].

$$
\frac{\text { Absorbance of standard }}{\text { Concentration of standard }}=\frac{\text { Absorbance of sample }}{\text { Concentartation of sample }}
$$

Vitamin E was determined by measuring $0.5 \mathrm{ml}$ of the sample into the test-tube I (centrifugal) with a tight stopper, about $0.5 \mathrm{ml}$ of anhydrous ethanol was added and shake vigorously; the test tube was plugged for 1 minute. About $3 \mathrm{ml}$ of xylene was added, the test tube was plugged and vigorously shaken for another $1 \mathrm{~min}$. The tube was centrifuged to separate the extract $(1500 \times g, 10$ minutes); simultaneously, $0.25 \mathrm{ml}$ solution of batophenanthroline was measured into test-tube II. About $1.5 \mathrm{ml}$ of the extract (upper layer) was collected and transferred, into the test-tube II and mixed.

About $0.25 \mathrm{ml}$ of $\mathrm{FeCl}_{3}$ solution was added to the test tube II, mixed, and $0.25 \mathrm{ml}$ of $\mathrm{H}_{3} \mathrm{PO}_{4}$ solution was added and mixed again after which a test sample was obtained for spectrophotometric measurements. The standard sample was prepared $(0.5 \mathrm{ml}$ of the standard solution instead of the analyzed liquid) using trolox. Deionized water $(0.5 \mathrm{ml})$ water was added instead of anhydrous ethanol at the beginning of the analysis. The absorbance of the test sample Ax was measured and that of the standard sample As at 539nm against the blank test. Concentration cx of vitamin $\mathrm{E}(\mu \mathrm{M})$ in the analyzed liquid was calculated as indicated in Eq (1).

\subsection{Viscosity Determination}

Viscosity was analyzed as carried out using Rion-viscotester, model VA-04F. The heated jam samples were poured into the viscometer cup, the rotor was suspended into the sample to rotate and the values were determined in decipascal-second unit at varying temperatures of $30^{\circ} \mathrm{C}, 40^{\circ} \mathrm{C}$ and $50^{\circ} \mathrm{C}$ [14].

\section{6. pH Determination}

A pH meter (HANNA instruments, Model, 23044) was standardized with standard buffer solution 4.0 and 7.0. The $\mathrm{pH}$ was measured by inserting directly the electrodes into 10 $\mathrm{ml}$ beaker containing the sample, the value was read from the $\mathrm{pH}$ meter to know the level of alkalinity or acidity of the product. The $\mathrm{pH}$ meter was rinsed with distilled water immediately after use before proceeding to the next sample.

\subsection{Titratable Acidity Determination}

Titratable acidity was determined according to the method described by AOAC [15]. Blended portion of the samples (1 g) were weighed and put into $50 \mathrm{ml}$ centrifuge tube. About $10 \mathrm{ml}$ of distilled water was added the centrifuge tube. Afterwards, $1 \mathrm{ml}$ aliquot of the solution was taken into another $50 \mathrm{ml}$ centrifuge tube and $10 \mathrm{ml}$ of distilled water added to dilute the sample. The diluent $(10 \mathrm{ml})$ was titrated against $0.1 \mathrm{~N} \mathrm{NaOH}$ solution using phenolphthalein (2 drops) indicator percentage titratable acidity was calculated. The percentage citric acid was calculated using Eq (3).
$\%$ citric acid $=\frac{\text { volume of alkali used }}{\text { volume of sample }} \times 0.007 \times 100$

\subsection{Specific Gravity and Brix Determination}

The specific gravity was determined using the AOAC Official Methods of Analysis [13]. The brix was determined using hand-held Abbey refractometer.

\subsection{Sensory Evaluation}

The jam samples along with bread serving as a carrier was presented to 10 semi-trained panelists from Food Science and Technology Department, Federal University of Technology, Akure. Multiple comparison test was used and the panelists were asked to indicate their observations and rate the samples parameters; flavor, colour, taste, spread ability and overall acceptability. The analysis was carried out on the five (5) samples.

\subsection{Statistical Analysis}

Results were subjected to statistical analysis using SPSS statistical package (Version 17.0). Analysis of variance (ANOVA), Duncan's multiple range tests and mean \pm standard deviation was chosen to determine any significant difference among the samples [16].

\section{Result and Discussion}

\subsection{Proximate Composition of Composite Jam}

The result of the proximate analysis of the composite jam is presented in Table 2. The moisture content of the control (MFJ) was higher than the jam blends which range from 2.52 to $2.68 \%$. The difference in moisture is expected because of the heating process involved during heating. Moisture has a great impact on the shelf life of products [17]. Processing of jams resulted in water removal and thus concentration of food nutrients [18]. Moisture and dry matter levels of any food material is a measure of the shelf life of the food [19]. There was a significance $(\mathrm{p} \leq 0.05)$ difference between the MFJ sample and the composite jam (BWP1, BWP2, BWP3, and BWP4).

The crude fat content of the jam blends ranged from 1.96\% to $3.92 \%$, while the fat content of MFJ was very low $(0.29 \%)$. The data recorded was close to $3.81 \pm 0.03$ reported by Ajenifuja and Aina [20], except for sample MFJ and BWP4 which had low crude fat. This might be attributed to the ratio of composition of the fruit pulps. There was a significance $(p \leq 0.05)$ difference between the MFJ sample and the jam blends.

The ash content of the composite sample ranged from 0.27 to $0.38 \%$; MFJ had the highest ash content of $0.39 \%$. The ash content was lower compared to the data obtained for prickly pear jam [21]. Ash content gives an indication of minerals composition of food sample is very important in many biochemical reactions which aid physiological functioning of major metabolic processes in the body [19]. 
Table 2. Proximate Composition of Composite Jam.

\begin{tabular}{lllllll}
\hline Sample & Moisture (\%) & Fat (\%) & Ash (\%) & Fibre (\%) & Protein (\%) & CHO (\%) \\
\hline MFJ & $27.19 \pm 2.01^{\mathrm{a}}$ & $0.29 \pm 0.01^{\mathrm{d}}$ & $0.39 \pm 0.27^{\mathrm{a}}$ & $1.25 \pm 0.25^{\mathrm{b}}$ & $0.26 \pm 0.09^{\mathrm{d}}$ & $70.62 \pm 1.53^{\mathrm{c}}$ \\
BWP1 & $2.55 \pm 0.30^{\mathrm{b}}$ & $3.85 \pm 0.08^{\mathrm{ab}}$ & $0.29 \pm 0.08^{\mathrm{a}}$ & $1.90 \pm 0.51^{\mathrm{b}}$ & $7.45 \pm 0.01^{\mathrm{b}}$ & $83.96 \pm 0.75^{\mathrm{ab}}$ \\
BWP2 & $2.52 \pm 0.07^{\mathrm{b}}$ & $3.92 \pm 0.00^{\mathrm{a}}$ & $0.38 \pm 0.00^{\mathrm{a}}$ & $1.41 \pm 0.25^{\mathrm{b}}$ & $8.58 \pm 0.18^{\mathrm{a}}$ & $83.19 \pm 0.02^{\mathrm{b}}$ \\
BWP3 & $2.77 \pm 0.12^{\mathrm{b}}$ & $3.75 \pm 0.04^{\mathrm{b}}$ & $0.37 \pm 0.07^{\mathrm{a}}$ & $1.82 \pm 0.38^{\mathrm{b}}$ & $6.92 \pm 0.09^{\mathrm{c}}$ & $84.38 \pm 0.42^{\mathrm{ab}}$ \\
BWP4 & $2.68 \pm 0.58^{\mathrm{b}}$ & $1.96 \pm 0.04^{\mathrm{c}}$ & $0.27 \pm 0.04^{\mathrm{a}}$ & $3.03 \pm 0.68^{\mathrm{a}}$ & $6.75 \pm 0.09^{\mathrm{c}}$ & $85.32 \pm 0.65^{\mathrm{a}}$ \\
\hline
\end{tabular}

*Values are mean \pm Standard deviation of three replications.

Values followed by different letters are significantly $(P \leq 0.05)$ different from each other.

MFJ-Mixed FruitJam; Apricot: Pineapple (Reference)

BWP 1-Banana: Watermelon: Pineapple of equal ratio (33.33:33.33:33.34)

BWP 2-Banana: Watermelon: Pineapple of 25:50:25

BWP 3-Banana: Watermelon: Pineapple of 25:25:50

BWP 4-Banana: Watermelon: Pineapple of 50:25:25

There was no significant $(\mathrm{p} \geq 0.05)$ difference in the fibre contents all the samples. Sample BWP4 had the highest fibre value, while the MFJ sample had the lowest. There was a significant difference $(\mathrm{p} \leq 0.05)$ between sample BWP4 and the other samples.

The crude protein value of the jam samples ranged from $0.26-8.58 \%$; MFJ sample was the lowest $(0.26 \%)$ compared to the other blends $(7.45,8.58,6.92$ and $6.75 \%$ respectively). This result indicated that the blend samples had high protein content which was similar to the protein content of prickly pear pulp (7.02 - 8.51\%) [21]. Crude protein content of $3.08 \pm$ $0.02 \%$ was recorded for black-plum fruit [20]. There was a significant $(p \leq 0.05)$ difference between samples BWP3 and BWP4 on one hand; and samples BWP2, BWP1 and MFJ on the other hand. There was no significant $(p \geq 0.05)$ difference between samples BWP3 and sample BWP4.

The carbohydrate content of MFJ sample was low (70.62\%) compared to those of the blends (BWP1, BWP2, $\mathrm{BWP} 3$, and BWP4) which ranged from 83 to $85 \%$. The highest carbohydrate content observed in BWP4 might be attributed to the high carbohydrate content in banana [22]. A significance $(p \leq 0.05)$ difference was observed in the MFJ sample and the composite jam samples.

\subsection{Mineral Composition of the Jam}

The mineral contents of the jam samples are presented in Table 3. The mineral analysis indicated the presence of high amount of beneficial mineral elements such as iron (0.33-
$0.84 \mathrm{mg} / 100 \mathrm{~g})$, sodium $\quad(18.23-30.70 \mathrm{mg} / 100 \mathrm{~g})$, potassium $(59.50-80.77 \mathrm{mg} / 100 \mathrm{~g})$, calcium $\quad(1.17-1.73 \mathrm{mg} / 100 \mathrm{~g})$, and magnesium $(0.50-0.80 \mathrm{mg} / 100 \mathrm{~g})$ in the jam blends. This abundance minerals contents nearly coincide with data for lowcalorie Baladi rose petal jam [23], which also had abundance of potassium, sodium, magnesium, and calcium, but low in iron.

Macro-minerals are required in amounts greater than 100 $\mathrm{mg}$ while micro-minerals are required in amounts less than $100 \mathrm{mg}$ [24]. Potassium is a cofactor that functions in protein synthesis, activation of enzymes, major solute functioning in water balance and thus affecting osmosis, operation of stomata. Calcium is important in formation and stability of cell walls and in maintenance of membrane structure and permeability, activates some enzymes, regulates many responses of cells to stimuli. Magnesium improves the component of chlorophylls, activates many enzymes. Iron also improves the component of cytochromes, electron transport, activates some enzymes, and plays a role in chlorophyll synthesis [25].

The result revealed that sodium and potassium contents were the highest in all the samples (experimental and control). The sample blends had better and acceptable $\mathrm{K}$ : $\mathrm{Na}$ ratio (less than 1) compared to the control (greater than one). For the iron content, there was no significant difference $(p \geq 0.05)$ between samples BWP1 and BWP2, but there was significant difference $(\mathrm{p} \leq 0.05)$ between samples MFJ, BWP3 and BWP4. Sample BWP4 had the highest content of iron

Table 3. Result of the Minerals Composition of the Jam Samples ( $\mathrm{mg} / 100 \mathrm{~g}$ ).

\begin{tabular}{lllll}
\hline Sample & Iron & Sodium & Potassium & Calcium \\
\hline MFJ & $0.46 \pm 0.12^{\mathrm{c}}$ & $9.30 \pm 0.20^{\mathrm{e}}$ & $8.37 \pm 0.21^{\mathrm{e}}$ & $4.03 \pm 0.15^{\mathrm{a}}$ \\
BWP1 & $0.33 \pm 0.04^{\mathrm{d}}$ & $18.23 \pm 0.26^{\mathrm{d}}$ & $59.50 \pm 0.20^{\mathrm{d}}$ & $1.73 \pm 0.12^{\mathrm{b}}$ \\
BWP2 & $0.34 \pm 0.03^{\mathrm{d}}$ & $28.77 \pm 0.23^{\mathrm{b}}$ & $80.77 \pm 0.11^{\mathrm{a}}$ & $1.44 \pm 0.06^{\mathrm{c}}$ \\
BWP3 & $0.64 \pm 0.03^{\mathrm{b}}$ & $24.40 \pm 0.04^{\mathrm{c}}$ & $61.37 \pm 0.25^{\mathrm{c}}$ & $0.80 \pm 0.17^{\mathrm{b}}$ \\
BWP4 & $0.84 \pm 0.30^{\mathrm{a}}$ & $30.70 \pm 0.20^{\mathrm{a}}$ & $78.37 \pm 0.23^{\mathrm{b}}$ & $0.64 \pm 0.04^{\mathrm{b}}$ \\
\hline
\end{tabular}

*Values are mean \pm Standard deviation of three replications.

Values followed by different letters are significantly $(P \leq 0.05)$ different from each other.

MFJ-Mixed Fruit Jam; Apricot: Pineapple (Reference)

BWP 1-Banana: Watermelon: Pineapple of equal ratio (33.33:33.33:33.34)

BWP 2-Banana: Watermelon: Pineapple of 25:50:25

BWP 3-Banana: Watermelon: Pineapple of 25:25:50

BWP 4-Banana: Watermelon: Pineapple of 50:25:25 


\subsection{Vitamin Composition of the Jam Blends}

The results of the vitamin (A, C, and E) are presented in Table 4. From the result, vitamin $\mathrm{C}$ content was the highest; which is similar to the result obtained for vitamins $\mathrm{A}, \mathrm{C}$, and $\mathrm{E}$ analysis of fresh grape fruit jam [26]. Vitamins A, E and in particular vitamin $\mathrm{C}$ are some of the major non-enzymatic antioxidants in the body that produce health beneficial effects by scavenging free radicals [27]. The application of prolonged heat treatments on fruits, such as in the case of jams, can lead to important losses of the beneficial properties of these citrus fruits [26]. Vitamin C functions as a watersoluble antioxidant, and it is also an effective antioxidant that readily scavenges reactive oxygen species (ROS) and reactive nitrogen species (RNS). The Recommended Dietary Allowance for vitamin $\mathrm{C}$ is $75 \mathrm{mg}$ per day for women and 90 $\mathrm{mg}$ for men, for nonsmokers [28]. Sample BWP3 had the highest amount of vitamin $\mathrm{C}$ which might be as a result of high vitamin $\mathrm{C}$ in pineapples. The value of vitamin $\mathrm{E}$ is very low in all the samples.

Vitamin A (retinol) is required by humans for the normal functioning of the visual system. The recommended dietary allowance for vitamin $\mathrm{A}$ is $700 \mu \mathrm{g}$ of retinol activity equivalents (RAE) per day for women and $900 \mu \mathrm{g}$ per day for men [28]. Another main function of vitamin $\mathrm{A}$ is in the maintenance of growth and epithelial cellular integrity and immune function in the body.

Table 4. Vitamin Composition of the Jam Samples.

\begin{tabular}{llll}
\hline Sample & Vitamin A $(\boldsymbol{\mu M g})$ & Vitamin C $(\mathbf{m g} / \mathbf{1 0 0 g})$ & Vitamin E $(\boldsymbol{\mu M g})$ \\
\hline MFJ & $1.98 \pm 0.01^{\mathrm{b}}$ & $3.68 \pm 0.52^{\mathrm{d}}$ & $0.04 \pm 0.00^{\mathrm{a}}$ \\
BWP1 & $3.58 \pm 1.21^{\mathrm{a}}$ & $3.68 \pm 0.18^{\mathrm{d}}$ & $0.02 \pm 0.00^{\mathrm{d}}$ \\
BWP2 & $1.32 \pm 0.00^{\mathrm{b}}$ & $8.22 \pm 0.52^{\mathrm{c}}$ & $0.02 \pm 0.00^{\mathrm{e}}$ \\
BWP3 & $1.69 \pm 0.03^{\mathrm{b}}$ & $10.31 \pm 0.18^{\mathrm{a}}$ & $0.03 \pm 0.00^{\mathrm{b}}$ \\
BWP4 & $1.36 \pm 0.04^{\mathrm{b}}$ & $9.27 \pm 0.18^{\mathrm{b}}$ & $0.02 \pm 0.00^{\mathrm{c}}$ \\
\hline
\end{tabular}

*Values are mean \pm Standard deviation of three replications.

Values followed by different letters are significantly $(P \leq 0.05)$ different from each other.

MFJ-Mixed Fruit Jam; Apricot: Pineapple (Reference)

BWP 1-Banana: Watermelon: Pineapple of equal ratio (33.33:33.33:33.34)

BWP 2-Banana: Watermelon: Pineapple of 25:50:25

BWP 3-Banana: Watermelon: Pineapple of 25:25:50

BWP 4-Banana: Watermelon: Pineapple of 50:25:25

Vitamin $\mathrm{E}$ is a chain-breaking antioxidant. It protects lipids against peroxidation. The recommended dietary allowance for vitamin $\mathrm{E}$ is $15 \mathrm{mg}$ for both men and women [28].

\subsection{Viscosity of the Jam Blends}

Viscosities of the jam at different temperatures are represented in Table 5. Generally, there is a decrease in the viscosity value of the samples as the temperature increases. The high viscosity could be attributed to high fiber content and most especially, to the concentration of pectin [29].

At $30^{\circ} \mathrm{C}$, there was no significance $(\mathrm{p} \geq 0.05)$ difference between samples BWP1 and BWP2, but there was a significance $(\mathrm{p} \leq 0.05)$ difference between these samples and samples BWP3, BWP4 and MFJ. At $40^{\circ} \mathrm{C}$ and $50^{\circ} \mathrm{C}$, there was a significance $(\mathrm{p} \leq 0.05)$ difference between the samples. One of the most important parameters that have an effect on viscosity is temperature [15].

Table 5. Result of the Viscosity Analysis of Jam Samples (dPa/sec).

\begin{tabular}{llll}
\hline Samples & Viscosity @ $\mathbf{3 0}^{\circ} \mathbf{C}$ & Viscosity @ $\mathbf{4 0}^{\circ} \mathbf{C}$ & Viscosity @ $\mathbf{5 0}^{\circ} \mathbf{C}$ \\
\hline MFJ & $139.67 \pm 0.58^{\mathrm{c}}$ & $100.67 \pm 0.58^{\mathrm{c}}$ & $90.00 \pm 0.00^{\mathrm{c}}$ \\
BWP1 & $280.00 \pm 0.00^{\mathrm{b}}$ & $135.67 \pm 1.15^{\mathrm{a}}$ & $121.33 \pm 1.15^{\mathrm{b}}$ \\
BWP2 & $280.33 \pm 0.58^{\mathrm{b}}$ & $110.33 \pm 0.58^{\mathrm{b}}$ & $80.00 \pm 0.00^{\mathrm{d}}$ \\
BWP3 & $90.33 \pm 0.58^{\mathrm{d}}$ & $48.33 \pm 0.58^{\mathrm{d}}$ & $45.00 \pm 0.00^{\mathrm{e}}$ \\
BWP4 & $300.00 \pm 0.00^{\mathrm{a}}$ & $135.00 \pm 0.00^{\mathrm{a}}$ & $129.67 \pm 0.58^{\mathrm{a}}$ \\
\hline
\end{tabular}

*Values are mean \pm Standard deviation of three replications.

Values followed by different letters are significantly $(P \leq 0.05)$ different from each other.

MFJ-Mixed Fruit Jam; Apricot: Pineapple (Reference)

BWP 1-Banana: Watermelon: Pineapple of equal ratio (33.33:33.33:33.34)

BWP 2-Banana: Watermelon: Pineapple of 25:50:25

BWP 3-Banana: Watermelon: Pineapple of 25:25:50

BWP 4-Banana: Watermelon: Pineapple of 50:25:25

\subsection{Specific Gravity Value of the Jam Blends}

The results of the specific gravity of the jam samples are presented in Table 6. The result showed that MFJ sample has the highest value. The result of the experimental composite jam sample ranged from 1.00-1.02, while the MFJ sample had 1.35 as the specific gravity value. There was significance $(p \leq 0.05)$ difference between MFJ sample and other samples. There was no significance $(\mathrm{p} \geq 0.05)$ difference between samples BWP1, BWP3 and BWP4. 
Table 6. Specific Gravity Analysis of the Jam blends.

\begin{tabular}{ll}
\hline Sample & Mean \\
\hline MFJ & $1.35 \pm 0.01^{\mathrm{a}}$ \\
BWP 1 & $1.00 \pm 0.00^{\mathrm{c}}$ \\
BWP 2 & $1.02 \pm 0.00^{\mathrm{b}}$ \\
BWP 3 & $1.02 \pm 0.00^{\mathrm{b}}$ \\
BWP 4 & $1.02 \pm 0.00^{\mathrm{b}}$ \\
\hline
\end{tabular}

*Values are mean \pm Standard deviation of three replications.

Values followed by different letters are significantly $(P \leq 0.05)$ different from each other.

MFJ-Mixed Fruit Jam; Apricot: Pineapple (Reference)

BWP 1-Banana: Watermelon: Pineapple of equal ratio (33.33:33.33:33.34)

BWP 2-Banana: Watermelon: Pineapple of 25:50:25

BWP 3-Banana: Watermelon: Pineapple of 25:25:50

BWP 4-Banana: Watermelon: Pineapple of 50:25:25

\subsection{Total Titratable Acidity, pH and Brix Values of the Jam Blends}

The TTA, $\mathrm{pH}$ and brix value of the jam samples are presented in Table 7. The $\mathrm{pH}$ values ranged from 3.55- 4.70, with the sample MFJ having the lowest $\mathrm{pH}$. The $\mathrm{pH}$ in the present study was slightly lower than that of jackfruit [17] and pineapple jam [23] which ranged from 4.8 to 6.3 in low calorie baladi rose petals jam. The $\mathrm{pH}$ of jam is an important factor to obtain optimum gel condition.
Table 7. Total Titratable Acid $(\mathrm{g} / \mathrm{ml}), \mathrm{pH}$, and Brix $\left(^{\circ}\right)$ Analysis of Jam.

\begin{tabular}{llll}
\hline Sample & TTA & pH & BRIX \\
\hline MFJ & 1.22 & 3.55 & 117 \\
BWP 1 & 0.49 & 4.7 & 128 \\
BWP 2 & 0.49 & 4.4 & 126 \\
BWP 3 & 0.63 & 4.16 & 129 \\
BWP 4 & 0.49 & 4.27 & 117 \\
\hline
\end{tabular}

*Values are mean \pm Standard deviation of three replications.

Values followed by different letters are significantly $(P \leq 0.05)$ different from each other.

MFJ-Mixed Fruit Jam; Apricot: Pineapple (Reference)

BWP 1-Banana: Watermelon: Pineapple of equal ratio (33.33:33.33:33.34)

BWP 2-Banana: Watermelon: Pineapple of 25:50:25

BWP 3-Banana: Watermelon: Pineapple of 25:25:50

BWP 4-Banana: Watermelon: Pineapple of 50:25:25

The acidity value of the jam blends ranged from 4.16-4.7 (\%). The acidity level of the samples was in a descending order of $4.7(\mathrm{BWP} 1)>4.4(\mathrm{BWP} 2)>4.27(\mathrm{BWP} 4)>4.16$ $(\mathrm{BWP} 3)>3.55(\mathrm{MFJ})$. Sample MFJ had low $\mathrm{pH}$ value and the highest acidity level, followed by sample BWF3 which had high $\mathrm{pH}$, with low acidity level which agrees with a previous work on juices and jams [18]. The brix value of the sample ranged from $117^{\circ}-129^{\circ}$.

\subsection{Sensory Evaluation of the Jam Samples}

Table 8. Sensory Evaluation Analysis of the Jam Samples.

\begin{tabular}{|c|c|c|c|c|c|}
\hline Sample & Flavour & Colour & Taste & Spreadability & Overall Acceptability \\
\hline MFJ & $5.00 \pm 0.00^{\mathrm{a}}$ & $5.00 \pm 0.00^{\mathrm{a}}$ & $5.00 \pm 0.00^{\mathrm{a}}$ & $5.00 \pm 0.00^{\mathrm{a}}$ & $5.00 \pm 0.00^{\mathrm{a}}$ \\
\hline BWP1 & $3.70 \pm 1.64^{\mathrm{a}}$ & $2.60 \pm 2.01^{\mathrm{bc}}$ & $5.50 \pm 2.46^{\mathrm{a}}$ & $5.00 \pm 1.15^{\mathrm{a}}$ & $4.30 \pm 1.77^{\mathrm{a}}$ \\
\hline BWP2 & $3.80 \pm 1.99^{\mathrm{a}}$ & $3.20 \pm 2.10^{\mathrm{bc}}$ & $5.30 \pm 1.83^{\mathrm{a}}$ & $5.20 \pm 1.40^{\mathrm{a}}$ & $4.70 \pm 1.57^{\mathrm{a}}$ \\
\hline BWP3 & $4.50 \pm 1.65^{\mathrm{a}}$ & $3.70 \pm 1.64^{\mathrm{ab}}$ & $6.20 \pm 1.75^{\mathrm{a}}$ & $6.10 \pm 1.37^{\mathrm{a}}$ & $5.70 \pm 1.77^{\mathrm{a}}$ \\
\hline BWP4 & $3.40 \pm 1.90^{\mathrm{a}}$ & $2.10 \pm 1.29^{c}$ & $4.70 \pm 1.77^{\mathrm{a}}$ & $5.40 \pm 1.51^{\mathrm{a}}$ & $4.2 \pm 2.15^{\mathrm{a}}$ \\
\hline
\end{tabular}

*Values are mean \pm Standard deviation of three replications.

Values followed by different letters are significantly $(P \leq 0.05)$ different from each other.

MFJ-Mixed Fruit Jam (Apricot and pineapple)

BWP 1-Banana: Watermelon: Pineapple of equal ratio (33.33:33.33:33.34)

BWP 2-Banana: Watermelon: Pineapple of 25:50:25

BWP 3-Banana: Watermelon: Pineapple of 25:25:50

BWP 4-Banana: Watermelon: Pineapple of 50:25:25

The sensory evaluation indicated that the jam blends was acceptable to the consumers (Table 8). The result showed that BWP3 and BWP2 recorded the best sensory evaluations, except for the colour and flavour. The high value of BWP3 could be as a result of high pineapple present; pineapple fruits are an excellent source of vitamins and minerals and supply arrays of colour, flavour and texture to the pleasure of eating [11].

Colour ranged from $21 \%-50 \%$ while flavor ranged from $34 \%-50 \%$ with sample BWP4 having the lowest in both cases. Color is an important sensory attribute on which the consumer preference depends.

Taste ranged from $47 \%$ - $62 \%$ with sample BWP4 having the lowest value while BWP3 had the highest. Spreadability ranged from $50 \%-61 \%$, with the control sample having the least while sample BWP3 had the highest.
Overall acceptability ranged from $42 \%-57 \%$. There was no significance $(\mathrm{p} \geq 0.05)$ difference in the panelist's preference for the flavour, taste, spread ability, and overall acceptability, however, there was significance $(\mathrm{p} \leq 0.05)$ difference in the colour, except for samples BWP1 and BWP2.

\section{Conclusion}

The proximate, minerals, and vitamins composition of the blends were nutritionally rich and better than commercial jam (control). The rheological behaviour of the blends could as well be comparable with that of the control. Jam consisting $25 \%$ banana, $25 \%$ watermelon and $50 \%$ pineapple have overall best sensory evaluation of $57 \%$. 


\section{Conflicts of Interest}

Authors declare there are no conflicts of interests

\section{References}

[1] Awolu, O. O., Omoba, O. S., Olawoye, O., \& Dairo, M. (2017). Optimization of production and quality evaluation of maize-based snack supplemented with soybean and tiger-nut (Cyperus esculenta) flour. Food science \& nutrition, 5 (1), 313

[2] Awolu, O. O., Osemeke, R. O., \& Ifesan, B. O. T. (2016). Antioxidant, functional and rheological properties of optimized composite flour, consisting wheat and amaranth seed, brewers' spent grain and apple pomace. Journal of food science and technology, 53 (2), 1151-1163.

[3] Ogundele, O., Awolu, O. O., Badejo, A. A., Nwachukwu, I. D., \& Fagbemi, T. N. (2016). Development of functional beverages from blends of Hibiscus sabdariffa extract and selected fruit juices for optimal antioxidant properties. Food science \& nutrition, 4 (5), 679-685.

[4] Fila, W. A., Itam, E. H., Johnson, J. T., Odey, M. O., Effiong, E. E., Dasofunjo, K., Ambo, E. E (2013) Comparative Proximate Compositions of Watermelon, Squash, and Rambutan. International Journal of Science and Technology 2 (1).

[5] Marjan Javanmard and Johari Endan (2010). A Survey on Rheological Properties of Fruit Jams. International Journal of Chemical Engineering and Applications, 1 (1): 31-37.

[6] Ploetz, R. C., Kepler, A. K., Daniells, J. and Nelson, S. C. (2007). Banana and Plantain - An Overview with Emphasis on Pacific Island Cultivars. Species Profiles for Pacific Island Agroforestry. (www. traditionaltree.org.), ver. 1.

[7] Adejoro, M. A., Odubanjo, A. O. and Fagbola, B. O. (2010). Research Focus on Banana and Plantain (Musa Spp.) Nigerian Perspective. In: Dubois, F. (ed.). Proceedings on banana and plantain in Africa held at NIHORT, Ibadan, Nigeria. Pp 859864.

[8] George E. Boyhan, Darbie M. Granberry and W. Terry Kelley (2000). Commercial Watermelon Production. The University of Georgia. College of Agricultural and Environmental Sciences and the U. S. Department of Agriculture cooperating, pp 1-32.

[9] Adekunle, A. A., Fatunbi, A. O., Adisa, S. and Adeyemi, O. A. (2007). "Growing Watermelon Commercially in Nigeria: An illustrated guide". USAID ICSNIGERIA and IITA.

[10] Ackom N. B and K Tano-Debrah (2012). Processing Pineapple Pulp into Dietary Fibre Supplement. African Journal of Food, Agriculture, Nutrition and Development, 2 (6).

[11] Othman O. C (2011). Physicochemical Characteristics and Levels of Inorganic Elements n Off-vine Ripened Pineapple (Ananas comosus L.) fruits of Dar es Salaam, Tanzania KIST. Journal of Science and Technology, 1 (1): 23 - 30.

[12] Barbara H. Ingham (2008). Making Jams, Jellies and Fruit Preserves. Wisconsin Safe Food Preservation Series.

[13] AOAC (2000). Association of Official Analytical Chemist.
Official Methods of Analysis $17^{\text {th }}$ edition, Washington DC.

[14] Awolu, O. O., Aderinola, T. A., \& Adebayo, I. A. (2013). Physicochemical and rheological behavior of African Star apple (Chrysophyllum albidium) juice as affected by concentration and temperature variation. Journal of Food Processing and Technology, 4, 229.

[15] AOAC, (2005). Official Methods of Analysis of AOAC International. 18th Ed., AOAC International, Gaithersburg, Md, USA.

[16] Rattanathanalerk, M., Chiewchan, N., \& Srichumpoung, W. (2005). Effect of thermal processing on the quality loss of pineapple juice. Journal of Food engineering, 66 (2), 259265.

[17] Eke-Ejiofor. J, Owuno. F. (2013). The Physico-chemical and Sensory Properties of Jackfruit (Artocarpus heterophilus) Jam. International Journal of Nutrition and Food Sciences. 2 (3): 149-152.

[18] Saka, J., Rapp, I., Akinnifesi, F., Ndolo, V. and Mhango, J. (2007). Physicochemical and Organoleptic characteristics of Uapacakirkiana, Strychnoscocculoides, Adansoniadigitata and Mangiferiaindica fruit products. International Journal of Food Science and Technology, 42 (7): 836-841.

[19] Ashaye, O. A. and Adeleke, T. O. (2009). Quality Attributes of Stored Roselle Jam. International Food Research Journal, 16: 363-371.

[20] Ajenifujah-Solebo, S. O. and Aina, J. O. (2011). PhysicoChemical Properties and Sensory Evaluation of Jam Made from Black-Plum Fruit (Vitex Doniana). African Journal of Food, Agriculture, Nutrition and Development, 11 (3).

[21] Atef, A. M. Abou-Zaid, Nadia, I. Ibrahim, Mostafa T. Ramadan and A. Nadir (2013). Quality Evaluation of Sheets, Jam and Juice from Prickly Pear and Melon Blends. Life Science Journal; 10 (2): 200-208.

[22] Franz Augstburger Franz, Jörn Berger, Udo Censkowsky, Petra Heid, Joachim Milz, Christine Streit (2001). Bananas Organic Farming in the Tropics and Subtropics. Naturlande. V, 2nd edition, pp 1-21.

[23] Hanan M. K. E Youssef, Rasha M. A. Mousa (2012). Nutritional Assessment of Low Calorie Baladi Rose Petals Jams. Food and Public Health, 2 (6): 197-201.

[24] Murray R. K., Granner D. K., Mayes P. A., Rodwell V. W., (2000). Harper's Biochemistry, $25^{\text {th }}$ Edition, McGraw-Hill, Health Profession Division, USA.

[25] Soetan K. O., Olaiya C. O., and Oyewole O. E (2010). The Importance of Mineral Elements For Humans, Domestic Animals And Plants: A Review. African Journal of Food Science, 4 (5): 200-222.

[26] Igual M., García-Martínez E., Camacho M. M., MartínezNavarrete N. Vitamin Content and Antioxidant Capacity of Grapefruit Jams and Candies Obtained by Different Dehydration Methods. European Drying Conference - Euro Drying'2011 Palma. Balearic Island, Spain, 26-28 October, 2011.

[27] Xu, G., Liu, D., Chen, J., Ye, X., Ma, Y., Shi, J. (2008). Juice Components and Antioxidant Capacity of Citrus Varieties Cultivated In China. Food Chemistry, 106: 545-551. 
[28] Annette Dickinson (2002). Recommended Intakes for Vitamins and Essential Minerals. from the Benefits of Nutritional Supplements, Council for Responsible Nutrition $(\mathrm{CRN})$.
[29] Abdelazim A. M. Nour, Khalid S. M. Khalidand Gammaa A. M. Osman (2010). Suitability of some Sudanese Mango Varieties for Jam Making. American Journal of Scientific and Industrial Research, 2 (1): 17-23. 